University of Nebraska - Lincoln

DigitalCommons@University of Nebraska - Lincoln

March 1984

\title{
Bioassay of Solubilized Bacillus thuringiensis var. israelensis Crystals by Attachment to Latex Beads
}

\author{
Danny J. Schnell \\ University of Nebraska-Lincoln \\ Mary Ann Pfannenstiel \\ University of Nebraska-Lincoln \\ Kenneth W. Nickerson \\ University of Nebraska-Lincoln, knickerson1@unl.edu
}

Follow this and additional works at: https://digitalcommons.unl.edu/bioscimicro

Part of the Microbiology Commons

Schnell, Danny J.; Pfannenstiel, Mary Ann; and Nickerson, Kenneth W., "Bioassay of Solubilized Bacillus thuringiensis var. israelensis Crystals by Attachment to Latex Beads" (1984). Papers in Microbiology. 75. https://digitalcommons.unl.edu/bioscimicro/75

This Article is brought to you for free and open access by the Papers in the Biological Sciences at DigitalCommons@University of Nebraska - Lincoln. It has been accepted for inclusion in Papers in Microbiology by an authorized administrator of DigitalCommons@University of Nebraska - Lincoln. 
Published in Science, New Series, Vol. 223, No. 4641. (Mar. 16, 1984), pp. 1191-1193. Published by the American Association for the Advancement of Science. Used by permission.

Submitted October 14, 1983; accepted December 28, 1983

\title{
Bioassay of Solubilized Bacillus thuringiensis var. israelensis Crystals by Attachment to Latex Beads
}

\author{
Danny J . Schnell*, Mary Ann Pfannenstiel, and Kenneth W. Nickerson \\ School of Biological Sciences, University qf Nebraska-Lincoln, Lincoln NE 68588 \\ * Present address: Department of Biochemistry and Biophysics, University of California, Davis 95616
}

Abstract: Solubilized crystals of Bacillus thuringiensis var. israelensis were 7,000 times less toxic to Aedes aegypti larvae than intact crystals, presumably because mosquito larvae are filter feeders and selectively concentrate particles while excluding water and soluble molecules. A procedure is described whereby soluble toxins are adsorbed to 0.8 micrometer latex beads, with retention of toxicity. The latex bead assay should make it possible to analyze the structure and mode of action of the mosquito toxin.

Control of several human diseases is based on controlling their mosquito or black fly vectors. Mosquitoes transmit such devastating diseases as malaria, encephalitis, yellow fever, dengue, and filariasis, while black flies transmit onchocerciasis. Biological control of these disease vectors has been made possible by the recent discovery of Bacillus thuringiensis var. israelensis (Bti). This bacterium produces a protein crystal during sporulation that is toxic to the larval stage of many mosquitoes and black flies. Purified particulate crystals are toxic to larvae of the mosquito Aedes aegypti at concentrations as low as $1 \mathrm{ng} / \mathrm{ml}$ (1). However, it has not been possible to determine the mode of action of the Bti toxin and the subunit of the multicomponent crystal $(1,2)$ containing the toxin. Larval toxicity disappears after the crystal is solubilized, probably because mosquito larvae, as filter feeders, selectively concentrate particles 0.5 to $10 \mu \mathrm{m}$ in diameter while excluding water and soluble molecules (3).

We report here a procedure whereby potentially toxic soluble proteins are adsorbed to latex beads with retention of toxicity. The soluble toxin gains access to the larval gut because the particles to which it is attached are of the appropriate size to be concentrated during filter feeding. This procedure should prove effective for use with other soluble, gut-active compounds toxic to filter-feeding mosquito and black fly larvae and to netmaking caddis flies, midges, and burrowing mayflies.

We confirmed that solubilized Bti proteins are still intrinsically toxic to mosquito larvae by adsorbing them to $0.8-\mu$ m latex beads (Table 1). The procedure was adapted from that described for the attachment of antibodies to latex beads (4). Bioassays were performed with second- to third-instar larvae of $A$. aegypti (5). The bead concentration was kept constant while the toxin concentration was varied through six or more dilutions covering the range from 100 to 0 percent mortality. Microscopic examination revealed larval guts gorged with ingested beads. The presence of excess beads minimized the effect of slight variations in larval number and size. Values of median lethal concentration $\left(\mathrm{LC}_{50}\right)$ were calculated after 4 hours instead of the more standard 24 hours because 4 hours approximates the larval transit time for nonnutritive particles in Culex pipiens (6) and because we wanted to avoid recycling of the beads. Values reported were calculated from three or more independent bioassays. Uncoated beads were not toxic to the larvae for at least 48 hours.

We confirmed that the solubilized Bti toxin was adsorbed by centrifuging the beads and washing them three times with $0.1 M \mathrm{NaPO}_{4}$ buffer $(p \mathrm{H}$ 7.4) containing 0.01 percent polyvinylpyrrolidone. Larval toxicity remained constant even after repeated washings. The amount of toxin attached to the beads was determined by labeling the proteins with ${ }^{125} \mathrm{I}$ and measuring bead-adsorbed radioactivity after the attachment and centrifugation procedures (Figure 1). The percentage of bead-attached proteins decreased from 80 to 45 percent as the protein concentration was increased from 2 to $37 \mu \mathrm{g} / \mathrm{ml}$. However, there was no preferential attachment of individual proteins to the beads. Sodium dodecyl sulfate-polyacrylamide gel electrophoresis (SDS-PAGE) profiles of the solubilized proteins before and after attachment were virtually identical.

Further bioassays in the absence of beads showed that solubilized Bti crystals were about 7,000 times less toxic than intact crystals (Table 1). When the solubilized proteins were adsorbed to latex beads of the appropriate size, the $\mathrm{LC}_{50}$ was reduced from 53,000 to $190 \mathrm{ng} / \mathrm{ml}$, a 280 -fold increase in toxicity. However, the $\mathrm{LC}_{50}$ for bead-attached toxin was still 25 times higher than that for intact crystals. This difference may reflect a decrease in toxicity on solubilization or an accumulation of physical factors due to the presence of the beads. Three possible physical factors are (i) decreased toxin ingestion due to the gut volume occupied by the beads and the longer transit time (6) caused by their nonnutritive status [merely mixing intact crystals with latex beads doubled their LC $_{50}$ (Table 1)], (ii) decreased toxin ingestion by the bottom-feeding

Table 1. Toxicity of soluble and crystalline Bti toxin to Aedes aegypti larvae. Crystals were prepared as described by Ang and Nickerson (9). The crystals $(2 \mathrm{mg} / \mathrm{ml})$ were solubilized overnight at $4^{\circ} \mathrm{C}$ in $0.05 M \mathrm{NaOH}(p \mathrm{H} 11.7)$ containing $10 \mathrm{mM}$ EDTA and were then centrifuged at $300,000 \mathrm{~g}$ for 30 minutes (10). The solubilized supernatant proteins were adjusted to 25 times the desired bioassay concentration in $1 \mathrm{ml}$ of $0.1 \mathrm{M}$ tris buffer $(p \mathrm{H} \mathrm{7.4})$ and mixed with $10 \mu \mathrm{l}$ of latex beads $(0.8 \mu \mathrm{m}, 10$ percent solids; Sigma). After incubation at room temperature for 1 hour the beads were centrifuged at $15,000 \mathrm{~g}$ for 10 minutes and the pellet was resuspended in $1 \mathrm{ml}$ of tris containing 0.01 percent polyvinylpyrrolidone (11). Test solutions were diluted with $24 \mathrm{ml}$ of deionized water for the bioassays. At least six dilutions of each toxin preparation were used; whenever latex beads were employed their final concentrations were identical. Values of $\mathrm{LC}_{50}$ were determined 4 hours after the addition of 10 to 20 larvae and are presented as means \pm 2 standard errors. All the experiments were conducted with crystal toxin from a single purification (12). The $\mathrm{LC}_{50}$ values for crystals remained constant over at least a 10-month period.

\begin{tabular}{lcc}
\hline \multicolumn{1}{c}{ Condition } & $N^{*}$ & $\mathrm{LC}_{50}(\mathrm{ng} / \mathrm{ml})$ \\
\hline Intact crystals & 5 & $7.5 \pm 1.6$ \\
Intact crystals mixed with latex beads & 4 & $15.0 \pm 2.6$ \\
Solubilized crystals & 3 & $5.3 \times 10^{4} \pm 1.1 \times 10^{3}$ \\
Solubilized crystals adsorbed to latex beads & 6 & $190 \pm 19.2$ \\
\hline
\end{tabular}

${ }^{*}$ Number of independent replications for each determination of $\mathrm{LC}_{50}$. 
Figure 1. Attachment of ${ }^{125}$ I-labeled Bti proteins to latex beads. Solubilized Bti protein was iodinated in vitro (13) to a specific activity of $4.9 \times 10^{7}$ count $/ \mathrm{min}-\mu \mathrm{g}$. Unincorporated ${ }^{125} \mathrm{I}$ was removed by chromatography on a Bio-Gel P6 column. The iodinated proteins were adsorbed to latex beads as described in the legend to Table 1 and the amount attached at each protein concentration was determined after centrifugation by measuring the radioactivity associated with the beads on a Beckman 5500 gamma counter. Assessment of bead-adsorbed proteins by dye binding (14) would have been inappropriate because this method indicates protein concentrations only 20 percent as high as those of three other methods. This difference is probably due to the fact that solubilized Bti proteins have a tendency to precipitate at acidic $p \mathrm{H}$ values. Each point is the mean \pm standard error for four determinations. The efficiency of attachment remained constant for live toxin purifications from three different Bti strains over a 10-month period.

A. aegypti larvae because the latex beads remain suspended during the 4-hour assay period while intact crystals settle to the bottom, and (iii) failure of the ingested toxin to be released from the beads. These factors in combination could account for most of the 25 -fold difference in $\mathrm{LC}_{50}$ values between intact crystals and bead-adsorbed proteins.

To determine the influence of these factors, we measured the levels of ingested, iodinated crystal proteins necessary to kill individual larvae (Table 2). Larvae were fed intact crystals, a mixture of beads and intact crystals, or bead-adsorbed solubilized proteins. After 4 hours the larvae were removed and the amount of labeled proteins in the guts of dead and live larvae was determined. Table 2 lists the amounts of toxin found in dead larvae that had been fed the three toxin preparations at concentrations approximating their respective $\mathrm{LC}_{50}$ values. We chose these concentrations because the amount of crystal proteins present in dead larvae decreased with decreasing external toxin concentration until leveling off near the $\mathrm{LC}_{50}$ values. At high toxin concentrations all the larvae were dead within 4 hours, whereas at concentrations near the $\mathrm{LC}_{50}$ values both live and dead larvae were observed in the same assay vessel. We draw three conclusions from the data in Table 2:

1) The presence of latex beads increased the lethal dosage for intact crystals about 2.4 times.

2) In the presence of an equivalent concentration of beads, solubilized Bti protein required only about 2.6 times more toxin than did intact crystals. Although the cause of this difference remains unknown, it is much less than the 25-fold difference in external $\mathrm{LC}_{50}$ values seen in Table 1 .

3) Larval mortality was a threshold phenomenon. Discrete threshold levels of

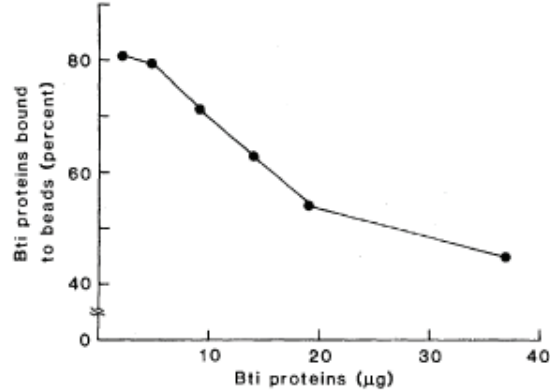

some of the implications that this bioassay has for research on mosquito abatement.

As mentioned earlier, the solubilized proteins were 7,000 times less toxic than the intact crystals. Previous estimates of the relative ability of water and particles to displace visible gut contents, such as activated charcoal, had put this factor at only 50 for $C$. pipiens larvae (3). Assurance that solubilized crystals are still intrinsically toxic should allow more accurate measurement of the larval filter-feeding factor in all insect species sensitive to Bti.

Analysis of the Bti crystal by SDSPAGE indicates that it consists of a single band at 28 kilodaltons $(\mathrm{kD})$; a triplet at 38,39 , and $40 \mathrm{kD}$; a single band at $53 \mathrm{kD}$; a doublet at 68 and $70 \mathrm{kD}$; and a doublet at 135 and $140 \mathrm{kD}$, with the percentage of each component varying among strains and batches. Availability of the latex bead bioassay will allow the separated protein chains to be bioassayed individually and in combination. Once the identity of the toxic protein is known, ${ }^{125}$ I-labeled toxin can be used to quantify the threshold level of toxin needed to kill a larva at each instar stage.

We found that our standard solubilization condition, $50 \mathrm{mM} \mathrm{NaOH}(p \mathrm{H}$ 11.7) with $10 \mathrm{~m} M$ EDTA, provided only variable and incomplete solubilization of the 135and $140-\mathrm{kD}$ protein bands. These bands could be completely solubilized by including $0.5 \mathrm{M}$ dithioerythritol, but this was not accompanied by enhanced larval toxicity. In agreement with others (2), we conclude that it is unlikely that the high molecular weight components of the crystal contribute to larval toxicity (7).

We recently showed (8) that the toxicity of intact Bti crystals to A. aegypti larvae could be reversed up to 100 -fold by levels of $\mathrm{K}_{2} \mathrm{CO}_{3}$ as low as 0.15 percent. At the time there was no way to determine whether this reversal was directly related to the crystal's mode of action or was merely preventing solubilization in the larva by lowering the gut $p \mathrm{H}$ below a critical value. However, the fact that $\mathrm{K}_{2} \mathrm{CO}_{3}$ achieved a similar toxicity reversal with bead-attached solubilized proteins indicates that the carbonate does not act by preventing eventual crystal solubilization.

Long-term control of mosquitoes with Bti is currently impractical because Bti does not persist in nature more than 1 or 2 days. Apparently the toxin settles into the mud or is consumed by other microorganisms. Attachment of the toxin to nonnutritive particles with a greater tendency to remain dispersed in water should enhance its persistence.
Table 2. Amounts of Bti proteins ingested by dead Aedes aegypti larvae. Solubilized proteins were iodinated as described in the legend to Fig. 1. Intact crystals were labeled in vitro with $\mathrm{Na}^{125} \mathrm{I}$ (13). After iodination the crystals were dialyzed for 24 hours against $0.1 M \mathrm{NaPO}_{4}$ buffer $(p \mathrm{H} 7.4)$ to remove unincorporated ${ }^{125} \mathrm{I}$. A specific acticity of $5.0 \times 10^{7}$ count $/ \mathrm{min}-\mu \mathrm{g}$ was obtained for the intact crystals. The $\mathrm{LC}_{50}$ value for labeled intact crystals was identical with that of the unlabeled crystals. The labeled toxin was diluted with unlabeled toxin to concentrations approximating their respective $\mathrm{LC}_{50}$ values (Table 1) and fed to larvae for 4 hours. The guts were dissected from dead larvae, which had been washed in 0.5 percent $\mathrm{NaCl}$ containing 0.1 percent SDS, and radioactivity was measured with a Reckman 5500 gamma counter. Data are means \pm standard errors.

\begin{tabular}{lrc}
\hline \multicolumn{1}{c}{ Condition } & $N^{*}$ & $\begin{array}{c}\text { Ingested } \\
\text { proteins } \\
\text { (nanograms } \\
\text { per dead } \\
\text { larva) }\end{array}$ \\
\hline $\begin{array}{c}\text { Intact crystals } \\
\begin{array}{l}\text { Intact crystals mixed } \\
\text { with beads }\end{array}\end{array}$ & 15 & $0.8 \pm 0.3$ \\
$\begin{array}{c}\text { Solubilized crystals } \\
\text { adsorbed to beads }\end{array}$ & 7 & $5.0 \pm 0.3$ \\
\hline
\end{tabular}

*Number of larvae dissected. 


\section{References and Notes}

1. D. J. Tyrell. L. I. Davidson, L. A. Bulla, W. A. Ramoska, Appl. Environ. Microbiol. 38, 656 (1979): D. J. Tyrell et al., J. Bacteriol. 145, 1052 (1981).

2. W. E. Thomas and D. J. Ellar, J . Cell Sci. 60, 181 (1983).

3. R. H. Dadd, J. Exp. Zool. 191, 395 (1975); Ann. Entomol. Soc. Am. 64, 687 (1971).

4. H. S. Abu Salih, A. F. Murant, M. J. Daft, J. Gen. Virol. 3, 299 (1968).

5. K. W. Nickerson and D. J. Schnell, J. Invertebr. Pathol. 42, 407 (1983).

6. R. H. Dadd, Entomol. Exp. Appl. 13, 407 (1970)

7. Dithioerythritol would interfere with iodination (13), and some sulfhydryl reagents exhibit larval toxicity in their own right [V. C. Kramer, D. J. Schnell, K. W. Nickerson, J. Invertebr. Pathol. 42, 285 (1983)]. Therefore we did not include dithioerythritol in our standard crystal solubilization conditions.

8. D. J. Schnell and K. W. Nickerson, Appl. Environ. Microbiol. 45, 1691 (1983).
9. B. J. Ang and K. W. Nickerson, ibid. 36, 625 (1978).

10. M. A. Pfannenstiel, E. J. Ross, V. C. Kramer, K. W. Nickerson, Fed. Eur. Microbiol. Soc. Microbiol. Lett. 21, 39 (1984) found that this procedure solubilized 80 percent of the crystal proteins, minimized proteolytic degradation (SDS-PAGE analysis gave gel profiles identical to those of intact crystals), and maximized the general cytolytic activity (2) exhibited by solubilized but not intact Bti crvstals toward human erythrocytes. Considering the multicomponent nature of the Bti crvstal, there is no guarantee that the mosquito larval toxin and the general cytolytic factor are identical. Also, since the crystal is incompletely solubilized and the pellet is still highly toxic to mosquito larvae, centrifugation at $100,000 \mathrm{~g}$ is necessary to define the solubilized toxin. Insufficient centrifugation probably explains the erroneous conclusion (1) that solubilized Bti crystals have $\mathrm{LC}_{50}$ values similar to those of whole crystals.
11. The $\mathrm{LC}_{50}$ values for solubilized proteins adsorbed to latex beads were identical in the presence and absence of the polyvinylpyrrolidone coating. The toxin-coated beads do not need to be purified before routine bioassays because the unattached solubilized proteins contribute negligibly to overall toxicity.

12. We have found that, when individual batches of purified Bti crystals are bioassayed for 4 hours against $A$. aegypti larvae, the $\mathrm{LC}_{50}$ ranges from 5 to $10 \mathrm{ng} / \mathrm{ml}$. Spontaneous loss of toxicity in Bti is common [H. Kamdar and K. Jayaraman, Biochem. Biophys. Res. Commun. 110, 477 (1983)].

13. M. A. K. Markwell and C. F. Fox, Biochemistry 17, 4807 (1978).

14. M. Bradford, Anal. Biochem. 72, 248 (1976).

15. K.W.N. is an NIH research career development awardee (A1 00327-TMP). This research was supported in part by University Genetics Company. 